UDC 781.4:1/14

Linos G. BENAKIS

\title{
BYZANTINE MUSICAL THEORY (HARMONICS) ${ }^{*}$
}

\begin{abstract}
Harmonics was one of the four mathematical sciences in the Byzantine higher education curriculum, together with Arithmetic, Geometry, and Astronomy (what was called quadrivium in the Latin West). Our knowledge of Byzantine harmonics is rather limited, as only two or three of the relevant treatises have been published in new editions. In this paper a systematic approach is attempted, while, at the same time, keeping distances from the well-studied practical aspect of Byzantine music, i.e. ecclesiastical music. Furthermore, the tradition of Greek musical theory (both Pythagorean and Aristoxenian), which the Byzantines developed further from a dual, both textual and educational, interest, presenting us at the same time with some original contributions.
\end{abstract}

Keywords: Byzantium, greek music, Harmonics, Quadrivium, pythagoreans, canonists, harmonists.

In recent years, a wealth of scholarly and layman's books have been written on Orthodox ecclesiastical music, its character, and history. There is intense interest in Orthodox church music in Greece and abroad, and thankfully our knowledge keeps expanding.

Yet when it comes to Byzantine musical theory, i.e. harmonics as a branch of science and philosophy in the Byzantine era, things are quite different. Here we are faced with a number of difficulties: although many critical editions, commentaries, and detailed hermeneutical works have been published on ancient Greek theoretical works on Music, the same cannot be said about the relevant Byzantine theoretical works. Several crucial scholarly issues remain unresolved; for instance: are there direct links between ancient

* In a short form published in Mousikos Logos

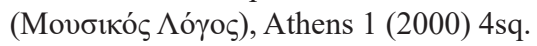

Greek harmonies (the kinds of octaves) and Byzantine musical scales (the system of the eight modes - oktōèchos), or does Byzantium represent a new starting point with eastern roots?

For a more systematic approach to this subject we would naturally need to draw a clear-cut distinction between music as it was practiced in Byzantium and Byzantine musical theory. Musical practice, the songs of the ancient world, of which we also know very little, was absorbed into Christian liturgical music and was overlaid by it, as with geological strata. Thus, by the time of Justinian $\left(6^{\text {th }}\right.$ century AD), when Byzantine ecclesiastical hymnology had come into its own as a discrete art form, practiced by magnificent Christian melodists such as Romanos, ancient Greek music was long dead. A Neoplatonic commentator of Aristotle, Olympiodorus of Alexandria tellingly claimed in the $6^{\text {th }}$ century that while enough ancient testimonies survive on the 
sciences of the ancients, such as arithmetic, geometry, and astronomy, precious little is known about ancient melody; in this case, a Homeric

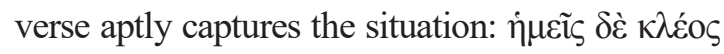

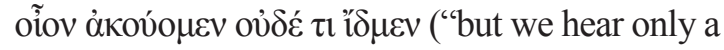
rumor and know nothing" Il. 2.486). Olympiodorus further adds that he only has access to theoretical works on ancient music.

Thus we need to draw a fundamental distinction: we should not confuse the musical practices of the Orthodox Church, what we call Byzantine music, with Byzantine non-ecclesiastical (thyrathen) music theory, i.e. the science of harmonics. The latter preserves several elements of ancient musical theory and continues its scientific tradition.

Thus, we do not know much about Byzantine musical theory. Until recently, interest in this field was limited to special philological and exclusively musicological research. There are but a handful of works written from a theoretical and philosophical perspective. Byzantine works on the subject were of interest to modern scholars only insofar as they helped them decode musical notation, apply the tonal system, and study its historical development i.e. as secondary sources for Byzantine ecclesiastical music.

Notwithstanding the lack of modern editions, however, of all Byzantine works on harmonics, and the absence of relevant treatises, it is certain that in this field we can detect an impressive continuity between ancient and later Greek musical theory. This thesis can now be supported more methodically on the basis of more recent assessments about specific musical theory works in the most recent of all the relevant studies (see Troelsgard, 1988). We should stress the fact that many manuscripts containing texts on harmonics are present throughout the
Byzantine era; this suggests an interest in copying, studying and employing texts of ancient musical theory as teaching material. Interest for teaching purposes eventually led to a dynamic and original reception and integration of ancient Greek musical theories in Byzantine teaching practices, and the composition of music textbooks; this is not confined to the field of harmonics as part of the quadrivium or tetractys of the mathematical sciences taught in Byzantine higher learning institutions: these texts were sometimes also put to use in the field of ecclesiastical music.

Thus harmonics, as taught in Christian Byzantium in the context of 'general education', or what we would describe as the thyrathen classicism of the Byzantines, allows us to follow how issues and scientific trends that emerged in Late Antiquity continued to occupy the thought of writers in the following centuries. As we shall see, Byzantine harmonics is also chiefly preoccupied with the tonal systems and their mathematical underpinnings, as it attempts to calculate their elements. By manner of introduction, what we need to underline again is that the subject of harmonics was cultivated solely in the higher schools of the empire and almost exclusively by the erudite philosophers who taught the relevant class on harmonics in the context of the quadrivium: arithmetic; geometry; harmonics; astronomy.

To describe the content of Byzantine musical theory we need to become acquainted with the ancient and late antique theoretical musical discussions and debates that continued during Byzantine times. One of the main currents in ancient Greek musical theory stems from the doctrines of Pythagoras, as expounded by Pythagorean philosophers throughout the ages. At its core lies the notion of numbers as the essence of 
the universe. For the Pythagoreans, harmony results from a synthesis of opposites; this holds true both for the cosmos as a whole and the soul, as well as in the regular (albeit unequal) distribution of melodic intervals in the tonal system. This is the direction of the so-called Canonists. Examples of Canonist musicians and philosophers are Archytas (430-360 BC), the single most important exponent of the theory, and later Pythagoreans until the time of Ptolemy (108-168 AD) and the Neoplatonic philosophers. The other direction is that of the School of the Harmonists; they were supporters of Aristoxenus, the eminent $3^{\text {rd }}$ century BC philosopher, who originated from Taras, but lived and taught in Athens. His work Elements of Harmony is extant, together with fragments from another one called Elements of Rhythm.

Following a rather long hiatus, from the $2^{\text {nd }}$ century $\mathrm{BC}$ to the $1^{\text {st }}$ century $\mathrm{AD}$, Pythagorean musical theories (those of the Canonists) flourished again, thanks to the great mathematician and astronomer Claudius Ptolemy. Ptolemy dedicated much of his studies to musical theory. His work Harmonics represents a philosophy of music, a study of the proportional nature of tonal relations, a proportionality that is echoed in the human soul and heavenly bodies. Ptolemy's Harmonics has been described as Antiquity's most insightful and most comprehensive synthetic work. Ptolemy's rational, systematic treatment of harmonics is of equal value to his astronomical work. The direction of the Pythagoreans was also adopted by Neoplatonic philosophers, i.e. the continuators of Plotinus' (205-270 AD) thought: Porphyry wrote in the late $3^{\text {rd }}$ century a Commentary on Ptolemy and discussed the logical distinctions between the quantity and the quality of tones; Iamblichus, active in the $4^{\text {th }}$ century, dealt with symbolic numerology and was influenced by eastern mysticism; and, finally, Proclus in the $5^{\text {th }}$ century composed valuable commentaries on Plato and Euclid. In this direction, and for all the philosophers mentioned, but also for many more, the purpose of mathematics and music/harmonics is to elevate man from the material world of the bodies and transport him to the Domain of the Ideas (or Forms), a realm of absolute beauty and perfect harmony. Mathematics, and the related sciences, astronomy and harmonics, exert a purifying and edifying influence on the soul. More specifically, harmonics as a philosophical and scientific field is founded on the imitation of divine harmony.

Under such presuppositions and in its purely theoretical character, the study and cultivation of harmonics during this period engendered a certain disdain and neglect for everyday lay musical practices. On the contrary, the Church Fathers, having embraced the Greek understanding of music's nature as an imitation (mimēsis) of divine harmony and a tool for promoting psychic health, welcomed the use of music in divine worship as it allowed people to listen to and comprehend the message of the Holy Scriptures more clearly. Thus musical practices not belonging to Christian liturgy continued to be sidelined in the following centuries, although later there is evidence for the use of songs in the rituals and celebrations of the Byzantine imperial court and in popular festivities.

Throughout the Byzantine period, harmonics or musical theory was cultivated and taught as a mathematical science, which in turn belongs to the supreme science, philosophy. Its subject-matter is chiefly the mathematical relations between tonal intervals. After all, the incorporation of harmonics in the four subjects (the so-called quadrivium) taught in the higher learning schools of Byzantium deflects interest 
away from music as artistic performance (musical act), refocusing it on the theoretical study of mathematical relations between sounds, harmonic calculations, and the relevant theoretical analyses. Therefore, music, as a science and a practice, was marginalized in education (both in terms of textbooks and teaching activity) and in the intellectual life throughout the Byzantine lands and throughout the western middle ages. To be precise, this was the case until the European Enlightenment, when new ideas led to the emergence of the view that music is a mimetic art and a creative activity. Around that time, musical theory as a branch of mathematics slowly began to disappear from the curricula of European higher schools.

A more systematic overview and more works on the position of musical theory in the context of Byzantine education are much needed now. Following the relocation of the capital of the Eastern Roman Empire to Constantinople, the city evolved into a great educational center, comparable to Hellenism's once famed centers of learning. In the time of Theodosius (425 AD), the Imperial University of Constantinople (Pandidakterion) had 30 chairs; among the courses taught we find Harmonics, always in conjunction with Arithmetic, Geometry, and Astronomy. During the reign of Heraclius (610641), in addition to theological sciences, this 'Ecumenical' school, as it was dubbed, also offered instruction on Greek sciences. These naturally included mathematics and harmonics. Two centuries later, we hear of the studies and the pursuits of the great dogmatist of the Eastern Orthodox Church, John of Damascus, who "was taught... mathematics, music, etc."

Higher learning experienced a phase great development following the establishment of University of the Palace Hall of Magnaura in the time of Bardas (863). Leo the Mathematician, or Philosopher, taught there, while import educators such as Photius, Arethas, a.o. were active there. During this period, and with the support of an erudite emperor, Constantine VII Porphyrogenitus, authorial output increased significantly and many ancient literature works were being copied, several of which were dedicated to the subject of harmonics. In 1970, E. Pöhlmann demonstrated that the work known as Introduction to the Art of Music by Bacchius Sennex is dedicated to Constantine VII, and not to Constantine I, as was earlier believed.

One of the earliest works on harmonics from the Byzantine era is by Monk Gregory Aneponymous Syntagma eusynopton eis tas tessaras mathēmatikas epistēmas, and was composed between 1008 and 1040. It was formerly ascribed to the great philosopher and polymath Michael Psellos, but nowadays we have at our disposal an excellent edition of this work by the great Dansh historian of ancient mathematics J. Heiberg, Anonymi Logica et Quadrivium cum scholiis antiquis, Copenhagen 1929).

It is important to note that in 1750 one of the pioneers of modern musicology R. Mizler $(† 1778)$, a German professor and publisher of a musicology periodical in Leipzig, attempted to publish Gregory's Music (harmonics) along with a German translation of the text. This is because Mizler, imbued with the rationalism of the great Christian Wolff, sought to find arguments that would allow him to promote music as a branch of mathematics (musica more geometrico) in university curricula. Thus Mizler singled out and highlighted the Prologue by that distant $11^{\text {th }}$ century Byzantine author, where he claims that "the harmony of the cosmos is borne out in Music"; that "Harmonics are grounded on the fact that harmony is the synthesis of diverse tones in a 
certain order"; and that the "purpose [of harmonics] is to study the constitution and the arithmetical relations between the symphonic intervals".

Of course, today we know more about this early work of Byzantine musical theory, and that its treatment of harmonics follows, up to a point, Aristoxenus' school (the Harmonists) and not that of Pythagoras (the Canonists); Mizler had failed to notice this. At any rate, the core of this work, i.e. its doctrine on the intervals, relies on the Pythagorean conception of arithmetical relations, as expounded by the brilliant mathematician Theon of Smyrna ( $1^{\text {st }}-2^{\text {nd }}$ century AD). In other words, at a critical point in the work, the Byzantine author switches from Aristoxenus' summation of intervals from sharp elements to the Pythagorean calculation of the arithmetical relations between the tones, i.e. his analysis of harmonics unfolds simultaneously on two levels. Nonetheless, the core of the work is Pythagorean, and this feature characterizes all Byzantine literature on harmonics.

Certainly, scholarship in this area is lagging both in terms of the degree of acquaintance with the available material, and its proper evaluation. That is why contributions, such as the one mentioned above by Chr. Troelsgard, are extremely valuable. His study also confirms the mixed nature of Byzantine harmonics (Troelsgard, 1988, pp. 230-232); interestingly, he further notes that works on ecclesiastical music, such as that by Hagiopolites, the earliest $\left(12^{\text {th }}\right.$ century) extant text of its kind (Hagiopolites, 1983), we find elements of ancient harmonics that are deemed useful in determining the appropriate level for teaching ecclesiastical music. Other extensive and systematic works on harmonics by Pachymeres and Nikephoros Bryennios can provide evidence on the features of musical practice (here of interest are the terms 'music', 'chant' and others, as well as the problems of employing string instruments in ecclesiastical musical practices).

Now, we will very briefly provide an overview of Byzantine authorial output in the field of harmonics from the $11^{\text {th }}$ century to the dissolution of the Byzantine Empire. Michael Psellos, the head (literally "chief") of the school of Constantinople (hypatos tōn philosophōn) was also known for his part in the reorganization of the curriculum in the "University of Constantinople" after 1045. He also composed an Introduction to Rhythmical Science and other minor works on music; this reveals the important place music held in the teaching of one of Byzantium's most prominent sages. In the lower grade of the new University, Grammar, Rhetoric and classical authors always formed part of the curriculum; the higher grade featured the quadrivium subjects and Philosophy (Logic and Natural Philosophy) and, depending on the course of study elected by the student, Jurisprudence or Medicine. An interesting detail reflecting these teaching practices is preserved in a work by the $12^{\text {th }}$ century author Nicholas Messarites. He describes how, in the School of the Saint Apostles in Constantinople, pupils received instruction on hymns and chants "in the enclosure" (these were first grade students); higher grade students, however, who took classes "in the courtyard", were taught harmonics. Thus it is once more clear that musical practice (hymns, songs) was separated from musical theory, which was taught in the context of "scientific" disciplines.

In the Palaeologan period (1261-1453), Byzantium's last period of flourishing in arts and letters, the subject of harmonics was widely taught in the "University", the Patriarchal Academy, and in other higher-learning schools; almost all of the erudite philosophers of these two 
centuries composed textbooks on harmonics. The most important names of this period are: Nikephoros Blemmydes in Nicaea and Ephesus; George Acropolites in the Hagia Sophia School; Maximos Planoudes (1255-1310), who composed a very extensive and unfortunately not extant Harmonics, where the astute author sums up the entire ancient Greek musical tradition; John Pediasimos; and, above all, the renown George Pachymeres. Pachymeres' (1242-1310) Quadrivium has been thankfully published in a critical edition (Tannery, 1940). The section on Music (harmonics) covers some 100 pages and is supplemented by many illustrations.

From the $14^{\text {th }}$ century onwards, Byzantine scholars become increasingly more interested in ancient Greek works, and chiefly in Aristoxenus, Ptolemy, and other later authors on music. A number of Byzantine commentaries on these works are composed. The lengthiest and most complete work on harmonics was produced, however, by Manuel Bryennios in ca. $1320^{1}$. Bryennios' work was preserved in a large number of manuscripts and in the late $15^{\text {th }}$ century it became known in the West thanks to a Latin translation by Franchinus Gaffurius.

Another eminent philosopher and astronomer, Theodore Metochites (1260-1332) analytically defined the essence of harmonics; he had studied under Manuel Bryennios. As a Christian humanist, he pondered on the possible benefits to be had from the study of harmonics on one's worldview: he argues that harmonics can bring people closer to the miracle of the harmony of the heavenly spheres, and God's perfection and omnipotence.

In the final years of the Byzantine Empire,

This work has also received an important modern edition: Manuēl Bryenniu Harmonika: The harmonics of Manuel Bryennius (ed) G. H. Jonker (Gronigen 1970). the number of original works on harmonics and of the manuscripts containing earlier works suggests the subject continued to be studied extensively. In these years, contacts with the West multiply, and Byzantium begins to exert increasingly greater influence on the Latin-speaking world; this phenomenon will reach its apogee with the flight of scholars from Byzantine lands to Italy after the fall of Constantinople. The final testimony on Byzantine musical theory is a brief work by George Gemistos or Plethon, the great philosopher of Mystras (1360-1452), and is entitled Some Chapters on Musical Theory. His student, the scholarly cardinal Bessarion, kept interest in the science of harmonics alive, as revealed by the large number of the relevant manuscripts he bequeathed to the Biblioteca Marciana in Venice.

As a conclusion, we can claim that as a higher learning scientific discipline, musical theory/harmonics in Byzantium remained firmly oriented towards the Pythagorean music theoreticians, Ptolemy, Nicomachus of Gerasa, Theon and others, who remained the authorities in the field of harmonics; their status remained unchallenged. Beyond the main musical commonplaces (topoi), which throughout the Byzantine era constituted a shared patrimony in musical education (parallel to the theoretical and arithmetical orientation of Byzantine harmonics, with respect to relations between intervals), musical philosophers were also well versed into Aristoxenus' doctrines on melody and rhythm; thus, Byzantine musical theory was anything but monolithic. At any rate, practical music textbooks (the so-called Papadikes) apparently continue precisely this practical (acoustic) method of Aristoxenus' school, albeit with a different purpose and in another context. Finally, it should be under- 
lined that the contemporary scholarly research, comprehensive in its methods and goals, scholarly research needs to clarify a series of questions before we will be in a position to speak with some degree of certainty about the great contributions of the Byzantines also in the field of music. $^{2}$

\section{REFERENCES}

Troelsgard, Ch. (1988). Ancient Musical Theory in Byzantine Environments. In $\mathrm{Ca}$ hiers de l'Institut du Moyen-Âge Grec et Latin, 56 (pp. 228-238).

Hagiopolites (1983). The Hagiopolites, A Byzantine Treatise on Musical Theory. In J. Raasted (Ed.), Cahiers de l'Institut du Moyen-Âge Grec et Latin, 45.

Tannery, P. (Ed.) (1940). Quadrivium de Georges Pachymère. (E. Stephanou, Ed.). Vatican City.

Bryennios, M. (1970). Manuēl Bryenniu Harmonika: The Harmonics of Manuel Bryennius (G. H. Jonker, Ed.). Gronige. 